ISSN(print): 2643-9840, ISSN(online): 2643-9875

Volume 04 Issue 03 March 2021

DOI: 10.47191/ijmra/v4-i3-10, Impact Factor: 6.072

Page No.- 282-297

\title{
Adorno and Avant-Garde Music
}

\section{Ricardo Mandolini}

ABSTRACT: My article explores some aspects of Theodor W. Adorno's work in relation to contemporary music in general and electroacoustic music in particular. Let us recall that Adorno never seriously considered the latter, which he regarded more as a technological bricolage than as a legitimate source for the production of works.

One of the purposes of this paper is to demonstrate that under the definition of musique informelle, Adorno opens wide the door to all musics, even those that do not depend directly on musical writing.

KEYWORDS: Musicology - Musical Semiology - Music - Heuristics

\section{PRELUDE}

My work proposes a new interpretation of Adorno's aesthetic theory, adapted and criticized in relation to our current needs, which are very different from those that arose at the origin of the philosopher's thought. In the first three points I attempt a broad interpretation of the key Adorno notions of musical material, content and form of the work, the dialectic of composition, the progress of musical material and the Warheitsinhalt (Truth content). I analyse the contradiction produced on the one hand by his search for objectivity in the work, (which tends to evacuate the personality of the composer), and on the other hand by his concept of musique informelle. The latter, well anchored in the subjectivity of the creator, is the source of Adorno's criticism of the musical avant-gardes of his time.

Point 5 analyses these criticisms, which can be interpreted first of all as a reflection of Adorno's inability to accept experimental models, mainly those that advocate the loss of control in the compositional process, the advanced use of chance in composition and the participation of the public in the aesthetic legitimisation of experiments. From this point of view, Adorno's doubts seem to be overtaken by a reality that has included chance in the aesthetic model since the 1960s. But they are also indicative of a need to relativize the technique, presented by the avant-garde as an absolute value, in relation to the compositional result. This problematisation of technique seems to me to be highly topical, since it is applicable not only to composition in general, but more specifically to acousmatic music, which is no longer in the age of discovery or phenomenological wonder, but which fatally suffers the consequences of its historicity. In this sense, Adorno can help us to find a relationship that enables acousmatic music to be less dependent on technology, avoiding the ageing at the root of all music on media. He can also help us to develop models of intelligibility in the fields of music creation and analysis.

Point 6 describes the situation of electroacoustic music today, trying to explain the importance that a rereading of Adorno can have, which will allow us to put the technique into perspective and to highlight the creative process above all.

\section{The two meanings of the concept of musical material: historicity and creative process.}

There is a terminological difficulty with Adorno's concept of musical material, which needs to be clarified from the outset. According to Anne Boissière, Adorno "designates the technical stage of an era, i.e. all the compositional problems that define a given period [...]. ${ }^{1}$ Moreover, "the musical material designates what is given shape in the composition, what the compositional gesture is based on and which is essentially relative to it [...]." 2

In his Aesthetic Theory, Adorno writes:

\footnotetext{
${ }^{1}$ « Le matériau désigne le stade de la technique d’une époque, c'est-à-dire l’ensemble des problèmes compositionnels qui définissent une époque déterminée [...]. »

Anne BoISSIERE, Adorno, la vérité de la musique moderne (The Truth in modern music), Villeneuve d'Ascq, Presses universitaires du Septentrion, 1999, p. 77. ${ }^{2}$ Ibid., p.78.
} 


\section{Adorno and Avant-Garde Music}

"The musical material is what the artists have at their disposal: what is presented to them in words, colours and sounds, to associations of all kinds, to the various technical processes developed; to this extent, forms can also become material [...]." ${ }^{3}$

So, on the one hand, there is the musical material that preexists the composer, and, on the other hand, the musical material transformed by the composer. The whole difference lies in the mediation of the artist's compositional activity, which has not yet taken place in the first case, but which is set in motion in the second. From this remark, we can retain that everything can become musical material, provided it is subjected to the compositional process. The musical material considered without regard to the artist's mediation could be described as "neutral". It is historical and represents a given period and its circumstances.

It is this meaning of the term that is at issue when Adorno says:

"The musical material can only be conceived as what the composer operates and works with. In this sense, it is nothing less than, objectified and critically reflected upon, the state of the technical productive forces that composers face in a given era." ${ }^{4}$

\section{Warheitsgehalt (Truth content) and "Progress of musical materials".}

We can call "shaped" the musical material transformed by the creator. In this second sense, musical material is presented as part of a creative process, related to what Adorno call the truth content of the piece. Adorno explains this fiction that serves to frame the creation of the work in the following way:

"Art can only be interpreted by the law of its movement, not by invariants. It is determined by its relationship to what it is not. 16

The fictional character of the truth content is expressed by the musical material in a sort of metaphysics that seeks to express the inexpressible:

"That which in the work of art transcends the factual, its spiritual content, cannot be associated with the particular sensitive given, but is constituted by it. It is in this that the mediated character of the truth content consists." ${ }^{6}$

As noted by Raymond Court:

"When Adorno describes the truth content of his work as metaphysical, he means something that is never secondary or retrospective, but resolutely non-empirical, prospective, in a word utopian." ${ }^{7}$

For Adorno, the work is not a present, but a future. Between these two moments lies what he calls the progress of the musical material, that is to say the set of transformations, the shape that the composer will give to the neutral material, while at the same time manifesting his intentions with regard to the historicity of this original material. ${ }^{8}$ This brings us to another key notion of Adorno, the dialectic of composition.

Theodor W. ADORNO, "Vers une musique informelle ", ("Towards an informal music") in Quasi una fantasia, traslation by JeanLouis Leleu assisted by Ole Hansen-Løve and Philippe Joubert, Paris, Gallimard, 1982, p. 302.

5 "L'art ne peut être interprété que par la loi de son mouvement, non par des invariants. Il se détermine dans le rapport à ce qu'il n'est pas. » Theodor W. ADORNO, Théorie esthétique, op. cit., p. 18.

6 "Ce qui dans l'œuvre d'art transcende le factuel, son contenu spirituel, ne peut être associé au donné sensible particulier, mais se constitue par celui-ci. C'est en cela que consiste le caractère médiatisé du contenu de vérité. » Ibid., p. 184.

$7 \quad$ Raymond COURT, Adorno et la nouvelle musique (Adorno and the new music), Paris, Klincksieck, 1981, p. 6.

8 The comparison between the Philosophy of New Music and the Aesthetic Theory together with Adorno's latest works, shows the evolution of the "progress of musical material". This is formerly

\section{The dialectic of the compositional process: characteristics and prerequisites.}

Adorno calls dialectic the construction process from which the work is built in reference to its future, already present in the chosen material. This concept can be taken up again for its great operational value, but with some reservations:

\footnotetext{
${ }^{3}$ « Le matériau, c'est ce dont disposent les artistes : ce qui se présente à eux en paroles, en couleurs et en sons, jusqu'aux associations de toutes sortes, jusqu'aux différents procédés techniques développés ; dans cette mesure, les formes peuvent également devenir matériau

[...]. »

Theodor W. AdORNO, Théorie esthétique, Paris, Klincksieck, 1995, new edition, translation by Marc Jiménez, p. 209.

${ }^{4}$ " Le matériau ne peut être conçu que comme ce avec quoi le compositeur opère et travaille. En ce sens, il n'est rien moins que, objectivé et réfléchi de façon critique, l'état des forces de production techniques auquel les compositeurs sont confrontés à une époque donnée. ॥
} 


\section{Adorno and Avant-Garde Music}

a) The eminently psychological and subjective character of the compositional process prevents a pure dialectical process between categories. The emotional content of the images and gestures used remains outside any dialectical process. This content is essential because it helps to determine the composer's style, and it cannot be dismissed or evacuated without explanation. In the psychological game of identification and repression that takes place in the work throughout the duration of the composition, the dialectic evolution is necessarily coloured by the emotional charge of the artist's images. Like every person, the creator is a complex mixture between conscious and unconscious motivations. If the dialectical movement fully realises its potentiality when one thing becomes, completely, something else, the existence of unconscious substrates, which are only partially realised within the process, makes its nature uncertain. Following the same idea, if several works belong to the same stage of unconscious problematic, the composer will probably work with musical materials and events that will present similar functions for his imagination, converging all towards the resolution of this problematic. These apparent "repetitions" from one work to the other, contribute to shape his personal style. Thus, his expression will be subject to causality - unknown to him, certainly, but not absent - rather than dialectic.

To sum up, the subjectivation of the process, from which, for example, Adorno constructs his remarkable immanent analysis of the work of Berg and Mahler, is to some extent incompatible with dialectic from the moment it is assigned to unconscious preconditions. Dialectic has served, not to reveal the compositional process but to avoid its psychological questions. According to Marcelo Zanardo: taken in the sense of pure novelty in the analysis of Schönberg's compositions (Philosophy of New Music) or, later on, just as the compositional exploitation of the material without regard to its objective novelty (Aesthetic Theory).

"Adorno contradicts himself. It is not uncommon to find these internal contradictions, very advanced, in interpretations that have a materialist dialectic of art and music in particular, which amounts to accepting the independence of music with its laws and its future, evacuating the creator, who is reduced to the role of a mere instrument. ${ }^{5}$

b) As we know, Adorno's ideal was to construct a structured aesthetic from direct confrontation with the works. It was not a question of elaborating a general theory that could complement the coherence of the philosophical edifice already in place (like Kant's Critic of judgement, for example, in relation to the two previous Critics) or applicate the systematic already exposed in previous works (for example, Hegel's Lessons in aesthetics applying the dialectic already developed in his Phenomenology of Spirit). Above all, Adorno took in consideration the individual and subjective value of the works. In accordance with this principle, - which is perfectly explicable when one remembers that Adorno knows and respects musical practice through his own experience as a composer -, he proposes to carry out a material theory of musical form on the basis of categories induced from the pure musical reality. Thus, he proceeds, like in his immanent analysis of Mahler's music, by forging a series of categories that are constructed, so to speak, from within the music, for instance "breakthrough", "fulfilment" or "suspension". These categories try to explain the individual by considering the work as a whole, as a sort of horizon of immanence always present. This conception is diametral opposed to the traditional categories of analysis which only identify recurrences and oppositions, and which separate the musical moment from its becoming.

Considering the dialectic of composition, these categories should be related, following Adorno, to a strong dialectic process. But this is not the case. The dialectic between Adorno's categories is absent; they multiply, they add up without ever referring to each other.

c) The fundamental question is how the work, while remaining subjective, realises its becoming: on this question depends the status of the relationship between material, content and form. Adorno seems to draw inspiration from two sources which partly intersect, but which originally appear to be fundamentally different: Hegel's dialectic and Bergson's creative evolution. On this subject, Michel Ratté has made the following analysis:

“I believe that the use of Bergson's theory confusedly expressed a desire to distance himself from the dialectical subject-object relationship in order to clarify how music is subject to itself: the immanent life of music - what is the immanent essence of informal music - in its immanent essence can only be an essentially subjective life. And here the question arises whether Adorno has not,

\footnotetext{
5 “[..] Adorno es contradictorio consigo mismo. No es raro encontrar estas contradicciones internas muy marcadas en quienes tienen una visión dialéctica materialista del arte y la música en particular, ya que se debería aceptar la independencia de la música con sus leyes y devenir, problema que deja afuera al hombre, el que es tan solo un instrumento."

Marcelo ZANARDO, "La dialéctica y el análisis musical”("Dialectic and musical analysis"), article online in www.monografias.com/trabajos15/analisis-musical/analisis-musical.shtml
} 


\section{Adorno and Avant-Garde Music}

through his metaphorical-heuristic recourse to Bergson's theory, avoided fundamental problems. In particular, whether a theory of "lived experience" (Erlebnis) can simply be grafted onto a dialectical theory of the experience of subjectivity. "10

Bergson postulates the becoming of subjectivity in terms of the past that could become our present, without being completely captured by this overcoming; part of the past would thus remain as an unchanged substratum. This movement should not be confused with dialectical overcoming, where one category becomes unequivocally totally different:

"[...] the realisation made possible by the emerging of our past, and the realisation as overcoming oneself in the other, are two absolutely different movements." 11

Taking into account all these reservations, it is possible to envisage the movement of dialectical overcoming in the compositional process, which, because of the substrates of subjectivity that condition it and which I have tried to describe

10 « Je crois que le recours à la théorie bergsonienne exprimait confusément la velléité de prendre une distance à l'égard du rapport dialectique sujet-objet pour éclaircir la façon dont la musique est sujette à elle-même : la vie immanente de la musique — à quoi se réduit (s'étend ?) au fond la musique informelle — dans son essence immanente ne peut être qu'une vie essentiellement subjective. Et là se pose la question de savoir si Adorno n'a pas, par son recours métaphoriqueheuristique à la théorie de Bergson, escamoté des problèmes fondamentaux. Notamment, celui de savoir si une théorie de l'“expérience vécue” (Erlebnis) peut simplement être greffée à une théorie dialectique de l'expérience de la subjectivité. »

Michel RATTE, "Le problème du devenir dans le concept adornien de musique informelle ("The problem of becoming in Adorno's concept of musique informelle") article online in: www.uqtr.uquebec.ca/AE/vol_3/ratte.htm

${ }^{11}$ « [...] le devenir rendu possible par la "poussée" d'un passé et le devenir comme dépassement

de soi dans l'autre sont deux mouvements absolument distincts. »

Ibid.

above, functions more as a regulator of the composition than as its constitutive principle. I think it would be possible to say that the compositional process functions as if it were dialectical, knowing that, in the final analysis, it is subjectivity that takes precedence and gives meaning to all speculation on becoming. What remains problematic in this relativisation is the way in which the work will acquire and legitimise its objectivity. By activating the principle of regulation borrowed from Kant's critical idealism, I propose here a kind of "de-ontologisation" of the dialectical process of creation and a recovery of its subjectivity. On the basis of this consideration, it is possible to continue to speak in terms of dialectic without losing sight of the fact that, in the final analysis, it is up to the composer and him alone to decide on the future of his creation. This introduces a flexibility of path allowing the creator to come and go throughout his artistic construction, deepening or changing ideas, images and gestures. Adorno does not share this view. Coinciding with Bergson, he affirms the irreversibility of the process that generates the work, from fluid to solid, passing through the stages of overcoming the polarised musical material towards the accomplished form. By considering dialectic as a regulatory and non-constitutive process of composition, I am denying, on the contrary, its irreversibility; the composer can always stop the dialectic movement, disengage from the work or move towards other goals he had not originally envisaged. It is up to his creative freedom to be able to go back and introduce changes he considers necessary at any level of the creative process. The possible reversibility of the process is necessary, given value to new, emergent choices. Nothing is obligatory for the composer, even if his strong commitment compels him to feel otherwise. Aristotle has understood this principle many centuries before Adorno :

"Every art is concerned with bringing something into being, i.e. with contriving or calculating how to bring into being some one of those things that can either be or not be, and the cause of whose production lies in the producer, not in the thing itself which is produced. For art has not to do with that which is or comes into being of necessity, nor with the products of nature; for these have the cause of their production in themselves. ${ }^{6}$

Moreover, ${ }^{7}$ Adorno never accepted that the simultaneity of possibilities could also become part of the creative process. This primordial question, which can no longer be resolved on the basis of the absolute overcoming of the work's categories, and which

\footnotetext{
${ }^{6}$ ARISTOTLE, The Nicomachean Ethics, translated by F. H. Peters, M.A. $5^{\text {th }}$ Edition (London, Kegan Paul, Trench, Truebner \& Co., 1893), Book VI, 4, p. 134, the online library of Liberty, Liberty Fund,

Inc., online in

https://oll-resources.s3.us-east

7 .amazonaws.com/oll3/store/titles/903/Aristotle 0328 EBk v6.0.pdf
} 


\section{Adorno and Avant-Garde Music}

implies thinking in terms of equiprobable possibilities, leads us to experimental models which will challenge objectivity in whole or in part. Against the closure of the work-entity, the work-process of the 1960s appears, introducing the hazard as an aesthetic paradigm and passing a good part of the control of composition to an audience that has become unavoidable in the aesthetic legitimisation of the musical work.

\section{Musique informelle - the question of notation}

"By musique informelle I mean music that would have freed itself from all the abstract and fixed forms imposed upon it from outside, but which, while not being subject to any external law alien to its own logic, would nevertheless constitute itself with an objective necessity within the phenomenon itself. " 8

This sentence by Adorno testifies to his rejection of allpowerful avant-garde musical systems on the one hand, and musical indeterminacy on the other. It remains to be defined now how musical writing is articulated in relation to a music that rejects any imposition from outside. Next, it will be imperative to define the status of improvised music in relation to informal music. Adorno answers these two questions:

"[...] music, like literature, is immobilised, spatialised by writing. The system of graphic signs they use converts succession into simultaneity, into stagnation. This contradiction is not external to them. What above all determines music as a process: the interweaving of thematic work, in which everything is held together, is only possible because it is fixed on paper; the complex forms of articulation by means of which succession is organised as such from within would be inappropriate for unwritten music based on improvisation [...]. However, by this antinomy between its solid state - that of a written score - and the liquid state to which it refers, music also participates in the character of appearance which is that of all evolved art [...]." ${ }^{\prime 9}$

In relation to Guy d'Arezzo's notation, it gives the creator, on one hand, the means to mediate images coming from his inner listening or imagination and, on the other hand, it provides him a tool to produce external combinatorial problematics. On the basis of this extremely complex semiological tool, the composers of Ars Nova and several theorists, such as Mersenne, developed an art in which the work is divided into two levels: structure, the central focus of principles and determinations outside musical time, and form, the direct application of these determinations in the work.

Inspired by this moment in the history of music, the avantgardes of the twentieth century took up composition by stages, which, due to its factorial origins, would be susceptible to generalisation. This idea was born with the series of pitches,(dodecaphonic music) and its application was later on generalised to series based on all musical parameters (serialism).

However, it must be said that between the twelve-tone series and the generalised series, there are two major differences:

1) At no time did the composers of the Vienna School make any act of tabula rasa in relation to their musical tradition; the historicity of the material was therefore assumed without hesitation in seeking a continuity that had, admittedly, become impossible. On the contrary, the avant-gardes of the twentieth century from 1945 onwards posed themselves explicitly against the musical tradition by trying to make a historical break with their past, a circumstance which Adorno can only criticise because of their self-referential egocentricity.

2) While the twelve-tone series controls the melodic and harmonic course of the pitches, the other parameters (rhythm, timbre, nuance, articulation) are composed intuitively as in the tradition. The internal coherence as well as the form of the work is ensured by the series of pitches, together with the other intuitive approaches. So is established, at least in theory, a fertile interaction between the two functions of musical notation mentioned above, namely the representation of images and the combinatorics of elements. This is in keeping with Adorno's

processus : l'entrelacement du travail thématique, dans lequel tout se tient, n'est possible que grâce à sa fixation sur le papier ; les formes d'articulation complexes au moyen desquelles la succession s'organise comme telle de l'intérieur seraient inappropriées à une musique non écrite, basée sur l'improvisation [...]. Cependant, par cette antinomie entre son état solide celui d'une partition écrite - et l'état liquide auquel il renvoie, la musique participe elle aussi au caractère d'apparence qui est celui de tout art évolué [...]. »

\footnotetext{
${ }^{8} \mathrm{~J}$ 'entends par musique informelle une musique qui se serait affranchie de toutes les formes abstraites et figées qui lui étaient imposées du dehors, mais qui, tout en n'étant soumise à aucune loi extérieure étrangère à sa propre logique, se constituerait néanmoins avec une nécessité objective dans le phénomène lui-même. "

Theodor W. ADORNO, « Vers une musique informelle », art. cit., p. 294.

${ }^{9}$ « [...] la musique, comme la littérature, sont immobilisées, spatialisées par l'écriture. Le système de signes graphique qu'elles utilisent convertit la succession en simultanéité, en statisme. Cette contradiction ne leur est pas extérieure. Ce qui détermine avant tout la musique comme
} 


\section{Adorno and Avant-Garde Music}

Theodor W. ADORNO, « Vers une musique informelle », art. cit., p. 315- 316.

Notion of informal music: the composer continues to control his work as a whole.

On the side of full serialism, writing tries to evacuate any intuitive possibility. Born out of Boulez's criticism of the Viennese's "meagre baggage" in relation to composition, generalised serialism tries to extend the system's control mechanisms to other parameters. The result is combinatorial arrangements with millions of possibilities, unpredictable because of their number, which prevent the composer from having an overall vision, simultaneous or successive, of his material and, worse still, from being able to keep the entire work in view. Confronted with an uncontrollable amount of information, the composer has, in principle, no selection criteria, neither quantitative nor qualitative, that would allow him to choose among the possible ones. He is obliged to retain or discard his material according to two procedures, both of which contradict the logic of the serial system: either choose by simple imposition of will, in which case the system bends to subjectivity, or choose at random, in which case the system withdraws from the organisation of form. But in either case, it becomes obvious that the system does not govern all the elements of the work, since certain decision-making areas escape it.

By short-circuiting any possibility of subjectivity within the creative process, generalised serialism unintentionally opens the door to instrumental experimental models, bearers of new writings. How to define these models? According to Dalhaus, the aim of these models is

"[...] to test the possibility of aestheticisation, or the aesthetic obviousness of materials or methods that are only partially subject to the control of composers." 10

Upstream, the centre of gravity of musical creation shifts, taking leave of the combinatorial force of traditional notation, to the side of listening, the core concern of composers in the 1960s. The new graphics lost the prescriptive character of traditional notation to become a kind of door open to various equiprobable possibilities or an invitation to improvisation. But formal music also evolved: as we know, stochastic music is structured on the basis of a reservoir of formulas drawn from its timelessness, which, updated in its time, remains solidly based on perception and listening. Moreover, Xenakis had the merit of having imagined an articulation between the two aesthetic paradigms of the late 1950s, by imagining a bridge between deterministic music and the probabilistic consideration of events. This means that a passage can be established between the notion of a closed work advocated by Adorno and the statistical and probabilistic models of musical conception. Xenakis does not want to express anything else when he states that stochastic music has transformed integral serialism into a special case, into a melodic line subsumed in a massive set of events.

At the same time, the Californian musical indeterminacy will add an unprecedented symbolic flexibility, to indicate the articulatory freedom of events that can occur within a framework defined at the outset. As a consequence derived from this conception, it will become possible to imagine composition according to the degree of determination or indeterminacy of actions, by arranging determination and probability on two bounds of a differential thought arranged in scale, in other words according to two parameters of composition in its own right. However, the appropriate writing is the one that best suits the degree of determination or indeterminacy of the compositional imagination.

Returning to Adorno's notion of musical notation, we need to reconsider his conception of "appearance" given by the dialectic between the stagnation of the writing and the dynamism of the material. First of all, Adorno did not postulate the necessity of an evolutive musical writing, that should be the logic consequence derived from his material theory of forms. Why this petrified conception of solfegetic musical notation, when everything that concerns music is for him a perpetual dynamic?

Secondly, Adorno does not seem to be receptive to the fact that traditional writing implies a very high degree of sophistication in the organisation of musical thought (the possibility of the "interweaving of thematic work", as he says), and that from the moment it is used, it is limited to a precise, event-driven determination, which is undesirable when it comes to represent the genesis of the compositional process. The latter needs a writing that is also in a state of gestation, fuzzy and vague in its genesis, like the gesture it is symbolising. The process of representation should be considered part of the process of creation. There is nothing irreversible about it, because the freedom of the creator is at stake when it comes to determining what kind of work he or she is creating and representing, be it a closed work, a more or less formalised game, an open work based on reservoirs of

\footnotetext{
${ }^{10}$ « [...]tester la possibilité d'esthétisation ou l'évidence esthétique de matériaux ou de méthodes qui ne sont soumis que partiellement au contrôle des compositeurs."

Carl DALHAUS, « La crise de l’expérimentation », in Contrechamps n³, l’Âge d’Homme Editions, 1984, p. $106-117$.
} 


\section{Adorno and Avant-Garde Music}

possibilities, or whatever. Moreover, the composer must be able to keep a retrospective view of his work, which allows him to go back at any time on the path he has taken and to change, if necessary, the initial premises in a methodology close to trial and error. Using only traditional notation to describe the process of genesis of a work implies an abrupt reduction of possibilities and leaves out compositional images that do not occur on the basis of writing. Adorno himself admits the difficulty of reconciling the notion of informal music with the thematic work made possible by traditional writing:

"It is not, however, a question of restoring the principle of thematic and motivational writing to the name "informal music", as an unshakeable a priori of composition. “11

As the imaginary becomes clearer, writing can also evolve as a necessity imposed from within, becoming more and more determined. Because it is generated within the phenomenon itself, this proposal of open semiology comes much closer to the definition of informal music than the one proposed by Adorno, characterised by the fixity in relation to the dynamism of the material. As for his assertion that "complex forms of articulation by means of which the succession is organised as such from within would be inappropriate for unwritten music based on improvisation", it attributes an apodictic value to traditional writing which leaves out all forms of unwritten expression. Traditional music, jazz, intuitive music, electro-acoustic music, etc. cannot, according to Adorno, claim to produce works because of their lack of fixity, making impossible what he calls "the dialectic of appearance." How can this additional requirement be reconciled with the notion of informal music?

According to Michel Ratté :

"The dialectic of appearance is directly tackled as a solution to the problem that is essentially immanent to music, namely how written music can, despite its fixation, be that of the spontaneous ear and concrete becoming - two ideals of "informal music". As a result, improvised music is deprived of any substance precisely because it contains the naivety of not bearing the weight of the "contradiction" of written music..."12

Here again, the problem Adorno faces is the objectification of the work, which leads to the romantic ideal of a closed and finished work, an absolute independent of its circumstances of production. For him,

“[...] as soon as the score finds its sound realization, as soon as the piece is played, it may be inscribed in empirical time and have its own chronometric duration, but it nevertheless seems to belong to yet another temporal order, the somewhat eternalized time of the written piece."13

This ideal is profoundly contradictory to the definition of informal music, which, in fact, refers to the circumstances in which the work was produced. In other words, the dialectic of appearance seeks to legitimise the work as an object, without considering the possible heuristic role of semiology. The definition of informal music, for its part, is the description of the work-process, of the work with a view to its objectification, the emphasis being placed on subjectivity in the process of constructing and re-constructing itself. According to Adorno,

"Informal music would be music in which the ear perceives, through living contact with the material, what has come out of $\mathrm{it}^{\prime \prime}{ }^{14}$

It seems plausible to me that music whose genesis is from polarised improvisation towards the realisation of a work could fulfil the conditions of the dialectic of musical composition and "Truth content" as Adorno conceives them, while falling within the definition of informal music. This reflection has enabled me to devise heuristic models for applying Adorno's principles, which I have applied both to instrumental composition and to electroacoustic music. ${ }^{15}$

\footnotetext{
11 «II ne s'agit pas, cependant, de restaurer sur le nom de "musique informelle", comme un a priori

indéfectible de la composition, le principe d'une écriture thématique et motivique. " Theodor W. AdoRNo, "Vers une musique informelle ", art. cit., p.323.

12 «La dialectique de l'apparence est directement plaquée comme solution au problème essentiellement immanent à la musique, de savoir comment la musique écrite peut, en dépit de sa fixation, être celle de l'oreille spontanée et du devenir concret - deux idéaux de la "musique informelle". Du coup, la musique improvisée est privée de toute substance justement parce qu'elle comporte la naïveté de ne pas porter le poids de la "contradiction" de la musique écrite... " Michel RATTE, art.cit.

13 « Dès que la partition trouve sa réalisation sonore, dès que le morceau est joué, il a beau s'inscrire dans le temps empirique et avoir sa durée chronométrique,

il semble néanmoins y appartenir à un autre ordre temporel encore, le temps en quelque sorte éternisé du morceau écrit. »

Theodor W. ADORNO, "Vers une musique informelle », art. cit., p. 317.

14 " une musique informelle serait une musique dans laquelle l'oreille perçoit, au contact vivant du matériau, ce qui est sorti de lui » Ibid., p. 337.

${ }^{15}$ To complete this point, see
} 


\section{Adorno and Avant-Garde Music}

\section{The discussion on the positivism of the avant-gardes, concrete and electronic music}

Adorno embodies the romantic and post-romantic attitude of European musical composition, which starts with Beethoven and goes all the way to the composers of the Vienna School, in what can be characterized as the aesthetics of musical works. The musical avant-gardes, for their part, which appeared at the end of the Second World War, accepted neither the historicity of the material nor the subjectivity of the creator as a criterion of aesthetic legitimisation. In fact, the new composers proposed novelties in all fields: graphic symbols to represent new repertoires of actions, different ways of using traditional instruments, new media for recording music. Concrete music and electronic music appeared in the early 1950s, giving a further argument to the absolute aesthetic value of materials and to the historical break characteristic of the avant-garde philosophy. Focused on Boulez and Cage, Adorno's critics were in fact aimed at the majority of young creators of the 1950s, who used devices or processes likely to legitimise their aesthetic: the series of integral serialism, the calculation of probabilities in stochastic music, the predetermined paths of the open work, the experimental nature of the electroacoustic material... These new ways of conceiving musical composition and its rules were, according to Adorno, highly reifying, in the sense that they tried to conceal the free will, the choice, the intuition of the composer, by hiding it under the folds of a highly formalised discourse. The ambition of these composers was to achieve scientific, objective, mechanical, automatic legitimisation of the work by setting aside the individual and his potential.

Concretely, Adorno criticised in his Aesthetic theory, as well as in the last articles of Quasi una fantasia, the radical attitude by which the compositional process is supplanted by the positivism of the materials used, both in Boulez's integral serialism and in Cage's musical indeterminacy. With this way of positing musical composition, the avant-gardes deny, on the one hand, the historicity of the material, and on the other hand, put aside the mediation of the subject-creator and his interaction with the material in order to produce the work. The identification of content and form - Boulez's interpretation of Levi-Strauss' structuralism - produces as a consequence a literality of the neutral material having as a precondition a pretension of immediate aesthetic legitimisation. Nothing was said about the subjectivity of the creator; subject and method separate. The music is made according to externally imposed rules and principles that construct an artistic objectivity from which the creative process is absent. In other words, in the name of the omnipotence of the systems and idiosyncrasies of the avantgarde, the composer gives up the idea of elaborating his own language from the musical material.

These principles postulate a starting point assumed by integral serialism and musical indeterminacy, which could be described as tabula rasa. But what for both of them is just avant-garde idiosyncrasy, becomes an inevitability for music on electroacoustic support. Its material and its way of composing has no history, everything has to be done, shaped and constructed; electroacoustic music is born fundamentally experimental. In the case of concrete music, the "self-referential enclosure" occurs on the écoute réduite (reduced listening), a proposal for a phenomenological cut-off of the sound from its source of production. This cut is capable of producing a new materiality of sound-in-self, outside its nature as a signifying clue to a signified reality. By reducing the phenomenon to its manifestation, the ear detects the sound object without associations, which can interact with other sound objects to produce concrete music. Nothing less astonishing than to see, under these conditions, how the handling of the material fully assumes the role of compositional process: one is the other.

Based on Pierre Schaeffer's definition of concrete music ${ }^{16}$, the musical form cannot be the projection of a globality that acts as the horizon of the realisation, since this intuition of globality would situate the work in the field of the abstract. It cannot be grasped by a potential virtuality, but is realised on the basis of multiple ways of handling the material.

Born in Cologne under the aegis of serialism, electronic music, for its part, proposes a series of techniques for producing and generating synthetic sound, distancing itself from the pre-existing material, recorded and then transformed, of concrete music. Responding to the serial principle of parallel arrangement of microform and macroform on identical structural principles, electronic composition has sought to create form from the characteristics of sound (spectral configuration, dynamic evolution of partials over time, etc.). This ideal came up against the state of the technology of the time, which did not allow, or hardly allowed, the generation of evolving and changing sounds.

Adorno, who doubted the possibility of a work without notation, showed a rather mixed relationship with electronic music, even though he had no knowledge of the subject: ${ }^{22}$

Ricardo MANDOLINI, « Heuristique musicale : contributions pour une nouvelle discipline musicologique » ("Musical Heuristics, contributions for a new musicological discipline"), editions Delatour France, 2012, p. $113 \mathrm{ff}$.

16 "We apply, as we have said, the term 'abstract' to everyday music, because it is first conceived by the mind, then noted theoretically, and finally performed in an instrumental performance. We have called our music "concrete" because it is constituted from pre-existing elements, borrowed from any sound material, be it noise or musical sound, then composed experimentally by direct construction, resulting in the realisation of a compositional will without the help, which has become impossible, of ordinary musical notation."

( "Nous appliquons, nous l'avons dit, le qualificatif d'abstrait à la musique habituelle, du fait qu'elle est d'abord conçue par l'esprit, puis notée théoriquement, enfin réalisée dans une exécution instrumentale. Nous avons appelé notre musique "concrète" parce qu'elle est constituée à partir 


\section{Adorno and Avant-Garde Music}

"No doubt the interest in electronic music has something to do with do-it-yourself, in an unclear way. It benefits from the way in which everywhere, including in the intellectual field, means replace ends [...]".

23

"It is already more plausible to think that electronics, which finally appeared as a technique outside the strictly musical technique, would rest outside the latter; that it would have nothing to do with the immanent kinetic laws of music." 24

d'éléments préexistants, empruntés à n'importe quel matériau sonore, qu'il soit bruit ou son musical, puis composée expérimentalement par une construction directe, aboutissant à réaliser une volonté de composition sans le secours, devenu impossible, d'une notation musicale ordinaire. ")

Pierre SCHAEFFER, « La musique mécanisée »(“Mechanised music”) in Polyphonie, Paris, Richard Masse, 1950.

22 "I myself have not worked in any studio, and am therefore not qualified by my own experience to pass judgment on the relationship between electronics and unity of musical meaning."

( « Je n'ai travaillé moi-même dans aucun studio, et ne suis donc pas qualifié, par ma propre expérience, pour porter un jugement sur les rapports de l'électronique et de l'unité de sens musical ».)

Theodor W. ADORNO, "Musique et nouvelle musique », dans Quasi una fantasia, op. cit., p. 287.

${ }_{23}$ "Sans doute l'intérêt que rencontre la musique électronique a-t-il partie liée, de façon trouble, avec le bricolage. Elle profite de la manière dont partout, y compris dans le domaine intellectuel, les moyens se substituent aux fins [...] »

Theodor W. ADORNO, "Musique et nouvelle musique », dans Quasi una fantasia, op. cit. p. $286 .{ }^{24}$ " II est déjà plus plausible de penser que l'électronique, qui finalement est apparue, en tant que technique, en dehors de la technique proprement musicale, serait extérieure à cette dernière; qu'elle n'aurait rien à voir avec les lois cinétiques immanentes de la musique. Ibid., p. 287.

Because of, among other things, the limited technical means available to composers at the time, Adorno failed to recognize the obvious connection between his definition of musique informelle and electroacoustic creation.

This is a question that was not formulated in his time, and which I think takes on new meaning as electroacoustic music matures.

\section{Current situation of electroacoustic music}

At its birth, electroacoustic music was in a state of grace due to its extreme novelty. Fifty years later, this situation has changed radically, as Daniel Teruggi noted:

"Pioneers always arouse the same admiration: the first discoveries, the first uses of tools, the first archetypal works, the first forays into unknown territories still retain the appeal of adventure, of jumping into the unknown. Today, there is no adventure [...]. Technological innovation has ceased to legitimise the approach of composers [...]. " 25

Today, electroacoustic music is caught up by its own history, in an era in perpetual evolution which no longer has the same questions as those of the pioneer years. Experimental proposals have become more the subject of mistrust towards the work than a horizon of expectations for creation. These proposals are partly utopian or seemingly contradictory. For example, does the search for a new sound not overlap with the preparation of a new listening style advocated by Schaeffer? Is not transforming listening a way of questioning the meaning of psycho-acoustic research, since a renewed listening would be likely to aim at the sound as a whole, independently of any research?

As a consequence of what we agree to call post-modernity - modernity called into question - critical approaches to contemporary music in general, and electroacoustic music in particular, are multiplying. It seems that a naive approach to contemporary music - one without questions about its conditions

25 « Les pionniers suscitent toujours la même admiration : les premières découvertes, les premières utilisations d'outils, les premiers archétypes d'œuvres, les premières incursions dans des territoires inconnus gardent l'attrait de l'aventure, du saut dans l'inconnu. Aujourd'hui, point d'aventure [...]. L'innovation technologique a cessé de légitimer la démarche des compositeurs

[...]. »

Daniel TERUGGI, "Quel esprit pour demain ? "("What spirit for tomorrow ?") in La Musique électroacoustique : un bilan (Electroacoustic music, a balance), articles compiled by Vincent Tiffon, Colloquium organized by Ricardo Mandolini and Vincent Tiffon, 2000, CEAC, Lille 3 University, p. 


\section{Adorno and Avant-Garde Music}

80.

of existence nor its possibilities for the future - is resolutely over. Paradoxically for an institution emblematic of the avant-garde, IRCAM does not seem to respond to these imperatives imposed by the times. An overview of the articles in the media library ${ }^{17}$ shows that, in a climate that is always euphoric about the benefits of technology and the resolution of problems in the computer environment for composition assistance, there is no room for the slightest questioning of the tool. From this point of view Philippe Manoury goes it alone when he asks:

"What does it mean to be modern today? The real stakes of a whole part of art over the last century and a half... have fallen into disuse. The famous phrases of Rimbaud and Baudelaire have become similar to a wave which, too damped, no longer allows its vibration to be perceived." 18

In fact, Adorno's critical rereading is a good pretext for taking stock of what seems to have remained truly revolutions and avant-gardes. In a climate of relativisation and revision, several sacrosanct truths of the art of rupture - over 50 years old - will have to be questioned. Thus goes, for example, the postulate defined by Boulez quoting Levi-Strauss: in art, form should be identical to content. This statement was severely questioned in the latter part of the last century by the proponents of the historicity or relativity of materials: Borges, Duchamp, Warhol, Danto, Goodman, and so many other creators and philosophers. This applies to all expressions, and music, even a few years away, is also beginning to take the path already begun by the plastic arts and literature. Thus, the key notions of work of art, creation and interpretation, material and technique must be reviewed, as Adorno states, in the light of historicity: it is no longer enough to speak of the work and its composer, it is necessary, explicitly, to allude to the period they reflect. The result of this approach is that one can start from the musical material of one work for the realisation of another, which differs from the first by the temporal management of events. This opens up a very vast experimental field and allows a new projection of the past into the future. The technique can provide us with other examples. For example, the cutting off of the attack transient of a sound takes on a completely different meaning depending on whether it is carried out in the early 1950s or today. In the first case, it produces an experimental and unheard sound, at a time when aesthetics and experimentation are strongly linked. In the second case, the experimental model alone is insufficient to make this sound an aesthetic object; in addition, there is a whole electroacoustic repertoire, made up of thousands of pieces composed throughout this half-century, which will make this gesture lose its character of novelty. Particularly in the case of electroacoustic music, we have seen, over the years, an abyss appearing between the aesthetics of the works on the one hand, and the technical means of production on the other. Electroacoustic music seems to have less and less need to hide behind scientific or experimental models. The latter have certainly been in crisis for some time now, and it must be admitted that the relative, the subjective and the psychological seem to be becoming more important in the discourse of creators and musicologists than the scientific discussions characteristic of other times. From this point of view, Adorno's discussion with the avant-garde of his time seems to have an inescapable topicality, re-actualising the value of the creator behind any attempt to reify the artistic.

Even if it remains directly dependent on technology, electroacoustic music is in a position to challenge the pact of solidarity with it in relation to common goals and shared ideals; this critical attitude must be able to be exercised despite the incantatory sirens of progress. Technology, far from fading, has shown extraordinary dynamism in recent years, evolving in a dizzying and unquestionable way. Never before have the means made available to users been so powerful, so efficient. As far as sound recording is concerned, we are reaching a level of quality that composers of other generations have certainly dreamed of. Our editing programmes allow the sound to be modified down to the last sample; our processing algorithms achieve everything imaginable in terms of possible manipulation of the signal. We can combine all the possibilities: scanner, score, MIDI, audio, sampling, synthesis... Moreover, the trivialisation of the CD recorder has completely changed our behaviour and habits with regard to the reproduction and publication of works, as well as the possibilities of distribution.

What do we reproach to the technique, then? What else could it have done other than evolve in an uninterrupted and optimal way?

First of all, we should ask ourselves whether technological perfection stimulates musical creation by allowing individual expression, or whether, conversely, individual expression risks being stifled within an ideological space that has been imposed on

\footnotetext{
${ }^{17}$ http://mediatheque.ircam.fr/articles/index.html

${ }_{18}$ "Que signifie aujourd'hui être moderne ? L'enjeu réel de toute une partie de l'art depuis un siècle et demi... est tombé en désuétude. Les phrases célèbres de Rimbaud et de Baudelaire sont devenues semblables à une onde qui, trop amortie, ne laisse plus percevoir sa vibration. "

Philippe MANOURY, "Le transitoire et l'éternel ou le crépuscule des modernes ? "("The transitory and the eternal or the twilight of the moderns?") in inHarmonique $\mathrm{n}^{\circ}$ 7, January 1991 : Musique et authenticité (1991/Manoury 91a).
} 


\section{Adorno and Avant-Garde Music}

it as a prerequisite. In reality, as we composers know, there are always two ways of dealing with technology; either in the right way, in the direction pre-determined by the machine and programme makers, or in the wrong way, trying to divert technology from the direction originally intended for its use. Pragmatically, each path is as valid as the other, from the moment it gives the hoped-for result: here is the musical heuristic in action. The importance of technique does not lie in its excellence, but in its capacity to produce artistic pathos, to grasp the music, to set the engine of art in motion. Technique is important as long as a composer can make it his own, and make it his own until it becomes an indivisible part of his expression. The main goal of the operation is that the technique be incorporated into the personality of the composer,

"[...] so that he can offer a vision of the world while at the same time talking about himself." 19

Faced with the strength of this identification, everything, even the charms of technological perfection, must be considered secondary, supplementary or allegorical. If the identification occurs in the context of a use presupposed by someone other than the composer himself, or if, on the other hand, it occurs in defiance of any prediction as to use, this is a matter of secondary importance to the creator. As far as aesthetics are concerned, there is nothing a priori to say whether the piece which pushes forward prior technological values is better - or worse - than the one which denies these values by diverting them. So, I think I detect here an important point of rupture between technique and aesthetics, given that their ideals are not necessarily shared: what is a matter of historical necessity for the former is only a choice of possibilities for the latter. From the point of view of technology, the history of electroacoustic music can be seen as the story of a simplification carried out on a number of devices, devices and compositional procedures that are very different from each other, which gradually transform themselves into functions and principles integrated into a systematic whole. The transition from analogue to digital technology is also an effort that can be explained by simplification; similarly, the supplanting of large equipment by microcomputing. This simplification certainly constitutes a technical ideal of optimisation of means, which, at the same time, reduces the overall cost of implementation and production to a minimum. The various stages through which the technology passes are linked by a ruthless historicity, induced by the search for optimal performance at the lowest cost: this is the technological ideal. The law of supply and demand is ultimately the main fuel of technological evolution, which explains why whole areas of research, computers and programs have a short life and are abandoned at the expense of others. An extremely painful case has occurred around the NeXT computer at Ircam, as Peter Szendi informs us:

"In spite of the progress that the SIM (Computer Music Station) represented, in spite of its worldwide diffusion, the announcement by manufacturers of the cessation of the manufacture of INTEL processors and then computers in 1992, accelerated a change for which IRCAM was preparing: in the future, developments will be untied from the hardware aspect to explore entirely software solutions. Today's commercial machines integrate real-time possibilities, which has become a real challenge well beyond music." 20

So, exit the custom-made computers for music research, and apply the MAX programme on Macintosh computers.

This is the abrupt end of the big computers such as the PDP and Minivax of the 70s, or the $4 \mathrm{X}$ of the 80s. Commercial microcomputers are catching up and quickly absorbing the efforts of pure research.

Who can guarantee that commercial programmes such as ProTools, or Studio Vision, or Cubase audio will not be able to supplant research environments and specialised software? The law of the market is ruthless and imposes its rules without the slightest consideration for the work already done. Here is what can be attributed to an ideology of standardisation, which can be deduced from Robert Moog's phrase:

"MIDI is not a universal standard, and certainly not the only possibility of electronic interface. But MIDI has been developed and proposed by several major equipment manufacturers". ${ }^{21}$

\footnotetext{
19 Philippe MANOURY, art. cit.

20 « Malgré le progrès qu'aura représenté la SIM (Station d'informatique musicale), malgré sa diffusion mondiale, l'annonce de la part de constructeurs de l'arrêt de la fabrication des processeurs INTEL et puis des ordinateurs en 1992, a accéléré une mutation à laquelle I'IRCAM se préparait : à l'avenir les développements seront déliés de l'aspect matériel pour explorer des solutions entièrement logicielles. Aujourd'hui les machines commer-ciales intègrent en effet les possibilités en temps réel, ce qui est devenu un véritable enjeu bien au-delà de la musique. » Peter SzENDY, " Musique, temps réel », Ircam (1988/Szendy 98b).

${ }^{21}$ Quoted by Peter Szendy in his article « De la harpe éolienne à la toile " ("From wind harp to the net"), Ircam (1996/Szendy 96d).
} 


\section{Adorno and Avant-Garde Music}

From the point of view of musical creation, electroacoustics cannot be conceived in the same terms; what is true for the technique is not necessarily true for the fantasy of the creators. The diversity of studios in the 1980s, and also the multiplicity of technologies within a single studio, contributed to a diversification of creative expression, at a time when everything remained either to be invented or discovered. Each creator had his own history, from the first contact with the studio and the means made available, to the complete appropriation, the complete mastery of the tool to which the work bears witness.

Inexplicably, no semiology of music considers the way in which the electroacoustic creative process is accomplished. In this sense, Adorno's notions of material progress and "truth content" are effective in describing the creative situation in the studio. How does it work? First of all, there is an objective framework of preconditions that serves as a support point for the imagination, where the work project is woven. Then there is a time for incorporating this framework, through experimentation and practice. At a certain point, the objective framework comes into line with the internal structures of the composer, who can thus attribute an objective value to his own projections. At this stage in the construction of the work, everything is in movement. There is a continuous back and forth between listening to the musical project on the one hand and the internal representation of the creator on the other. There is also a two-way path between what the composer imagines and what technology allows him to do. Given the complex richness of this process, an overall explanation is needed that can mobilise complementary knowledge of the various disciplines and methodologies involved, without losing sight of its dynamic fluidity. To my knowledge, the cognitive model, which is already very efficient in giving a global interpretation of hearing based on the continuous adequacy between mental representation and real perception, would be able to elaborate a clear and satisfactory explanation in the future.

"The originality of the cognitivist project is to present an integrated vision of the intellectuals processes involved by highlighting the continuity existing between the most elementary aspects of these activities (sensory information processing) and the most abstract aspects (symbolic information processing). Consequently, the cognitivist project goes beyond the traditional division into independent intellectual functions (perception, memory, learning, language, intelligence, etc.)."22

As part of the objective framework, the technology must interact very closely with the psychological structures of the creator so that the work can see the light. Irrespective of the excellence of the technology, it is imperative that the conditions for this interaction can be given. From this point of view, the best technique is not the most developed, but the one that motivates the creator and gives him wings to let his fantasy fly away. Where wings are not visible, the composer will try to obtain them. Here lies the importance of the possibility of diversion as a strategy for incorporating a technique. It was feasible at a time when machines and programs had not yet reached the present level of perfection. Today the ductility of technology prevents, or at least does not facilitate, its diversion. In other words, it seems more and more difficult to find a way of using it that is not foreseen from the outset by manufacturers or programmers; outside of this repertoire of prior possibilities, machines crash, or give us error messages. Nowadays almost everything seems to fit into the predictable order, which can be seen as an advantage or, on the contrary, a terrible disadvantage, according to the creators. Would it be possible, or desirable, to envisage in the future a degree of technological perfection adjustable between two limits, as if it were another parameter of the composition? I am not able to answer this question definitively. In a way, some current commercial programmes do, as long as they provide, for example, alongside the synchronisation control, for "human" synchronisation, knowing that the first is absolute while the second imitates the statistical margin of error.

To continue my comparison, it is easy to conclude that there has been progress, from a technological point of view, between the early sound generators and the synthesiser, or between the delayed-time programmes made available by the digital studios of the 70s and 80s, and today's assistive composing environments. Is the aesthetics of works evolving in parallel with this progress? First of all, it would be necessary to define what the word "progress" could mean in terms of artistic realisation. In addition,

“[...] art does not progress by successive accumulations but conquers certain fields for the benefit of others. In the 18th century, the gradual abandonment of specific temperaments made it possible to enrich a combinatorial approach. This did not go smoothly. Closer to our historic moment, the abandonment of the laws of tonal resolution favoured a rhythmic development that would not have been possible without it. Today, the use of materials, such as those used in electroacoustic music, which are more complex

\footnotetext{
22 « L'originalité du projet cognitiviste est de présenter une vision intégrée des processus intellectuels en mettant en évidence la continuité existant entre les aspects les plus élémentaires de ces activités (traitement de l'information sensorielle) et les aspects les plus abstraits (traitement de l'information symbolique). Par conséquent, le projet cognitiviste dépasse la traditionnelle division en fonctions intellectuelles indépendantes (perception, mémoire, apprentissage, langage, intelligence, etc. »

Stephen MCADAMS, Emmanuel BIGAND, « Introduction à la cognition auditive » (“Introduction to auditive cognition”) Ircam (1993/ McAdams 93b).
} 


\section{Adorno and Avant-Garde Music}

and without historical precedent, renders obsolete, in this precise field, a whole panoply of techniques related to instrumental music. It is in this movement that we should see what, for want of a better term, can be called evolution."

32

In order to be able to determine progress in the arts, specific criteria would have to be identified, which would determine the basis for a comparison. This is the great difficulty faced by the analyst and the historian. Without an overall purpose that can serve as a reference and framework, the concept of progress is arbitrary. It would lead us to take up again the famous manifestations of intolerance of the 1950s, and to illegitimately distribute bonuses and maluses among the pieces, in an era like ours, which distrusts any deontology of creation.

Neither technology nor research can provide these indispensable criteria. Nevertheless, the recovery of the data inside the works is done without any aesthetic consideration. This is the opinion of Hugues Vinet, former technical director of IRCAM :

"In the absence of a possible consensus on the musical quality or scope of the works, the evaluation of the research can only be carried out indirectly, through its social repercussions. It must therefore be

32 [...] l'art ne progresse pas par accumulations successives mais conquiert certains domaines au profit d'autres. Au XVIII' siècle, l'abandon progressif de tempéraments spécifiques a permis d'enrichir une combinatoire. Cela ne s'est pas fait sans heurts. Plus près de nous, l'abandon des lois de résolution tonale a favorisé un développement rythmique qui n'aurait pu voir le jour sans cela. Aujourd'hui, l'utilisation des matériaux, comme ceux de la musique électroacoustique, plus complexes et sans précédents historiques, rend caduque, dans ce domaine précis, toute une panoplie de techniques liées à la musique instrumentale. C'est dans ce mouvement qu'il convient de voir ce que l'on peut appeler, faute de mieux, l'évolution. » Philippe MANOURY, art. cit.

noted that the techniques used in the various fields of sound production, whether for popular music, sound with image or multimedia, have evolved considerably over the last fifteen years, often thanks to the integration of processes invented by the pioneers of musical creation. More generally, the methods developed for sound synthesis, the study of acoustic quality, the formalisation of musical languages or acoustic simulation are now finding industrial applications in the fields of automotive and transport, telecommunications, multimedia or design. From this, it is only a short step to deduce that the requirement that presides over creation precedes in its inventive scope any realisation motivated solely by commercial considerations."

33

The ideological space of technology can be defined as the set of decisions taken by those responsible for the hardware and software to optimise or facilitate the process for users. Since the appearance of computers applied to music, composition has been confronted with this type of decision, to which it has necessarily had to adapt. At the beginning of the 1980s, the various digital music studios in Europe (IRCAM, GRM, EMS in Stockholm, Sonology in Utrecht) made available to composers various music application programmes, made in heavy programming languages, such as FORTRAN, ALGOL, PASCAL, Lisp, etc., which were designed to be easy to use and to be used by composers. These first software programs for musical purposes were the result of the work of different teams of programmers, pioneers of digital electroacoustic music, without any possible consultation between teams. Result: even if they were running on the same computers, softwares were incompatible with each other. The composer who worked in several of these studios either had to learn all his application programmes in order to be able to carry out his work satisfactorily, or he had to work in a heavy programming language such as those I have just mentioned. In any case, he had to "translate" his musical thoughts into several semiologies, thus making a considerable effort of adaptation.

33 « En l'absence de consensus possible sur la qualité musicale ou la portée des œuvres, l'évaluation de la recherche ne peut être opérée qu'indirectement, à travers ses retombées sociales. Force est alors de constater que les techniques utilisées dans les différents domaines de la production sonore, qu'il s'agisse de musiques populaires, de son à l'image ou de multimédia, ont considérablement évolué au cours des quinze dernières années, souvent grâce à l'intégration de procédés inventés par les pionniers de la création musicale. Plus largement, les méthodes développées de la synthèse sonore, l'étude de la qualité acoustique, la formalisation de langages musicaux ou la simulation acoustique trouvent aujourd'hui des applications industrielles dans les domaines de l'automobile et des transports, de télécommunications, du multimédia ou du design. De là à en déduire que l'exigence qui préside à la création précède dans sa portée inventive toute réalisation uniquement motivée par des considérations marchandes, il n'y a qu'un pas. » Hugues VINET, « Les enjeux de la recherche et du développement technologique pour la création musicale » (The challenges of research and technological development for musical creation"), Ircam (1998/Vinet 98a). 


\section{Adorno and Avant-Garde Music}

Later, the studios became more user-friendly; the composer could influence the programming by giving his opinions and explaining his needs. I keep two examples of personal collaboration, one with engineer Bernard Feiten at the Technical University of Berlin, for the elaboration of an interpolation programme between various spectra. The other with Hugues Vinet, at the GRM, for the realisation of an algorithm for the simulation of the Doppler effect, which has now become one of the tools in the GRMTools menu.

With the massive advent of micro-computing, the historic studios were severely disrupted. First of all, from the home studio, a whole genre of creators tends to disappear; these are the itinerant composers of the 80 s, whose movements no longer have any reason to exist, since they obtain very good performances without having to move from home.

Secondly, due to a lack of commercialisation, there is the disappearance or the threat of disappearance of the prototypes developed by each studio. I have already mentioned the case of NexT. Other examples could be added, such as the GRM's Syter or the CeMAMU's UPIC. As far as research is concerned, programming remains a fundamental activity.

Thirdly, the activity of these studios must change direction, since the centre of gravity of musical production is beginning to depend on a wider audience, which now has access to tools that were once devoted to pure creation. Here a kind of vicious circle occurs. The typical users of the home studio are not composers of contemporary electroacoustic music. They are the real customers of the electroacoustic market, rock and popular music musicians in general. The whole electroacoustic trade and industry depends on their motivation, their predilections and their choices about what works and what doesn't work. Research in turn depends on the industry, since it is at least partly sponsored and endorsed by it. Conclusion: the margin of play for contemporary creators, as well as the motivation to continue to produce outside the commercial circuits, is very narrow. Where do we find it? For the most part, on aspects that are still beyond the reach of the home studio, such as the creation of environments to aid composition and musical analysis, with the resolution of specific problems: among others, quantification in the transition from material to writing, techniques for executing the work in real time, or acoustic simulation in spatialization, or multimedia.

To a lesser extent, the research is carrying out programmes that can be assimilated to consumer consumption, such as GRMTools, a menu of plug-ins compatible with ProTools. Max, for its part, was cradled by Macintosh before NexT and can continue to be used without any problem on this medium.

Today, the home studio has made large installations superfluous by democratising the means of electroacoustic production. The price to be paid is a growing trend towards uniformity of expression, all of which is ultimately based on a reduced number of computers and programmes.

But also on the research side, this danger is present. Thus, according to Daniel Teruggi:

"We have probably developed the essential algorithms for sound processing (many specialists think that it is difficult to invent new algorithms that could offer totally new sound processing)." 23

If this statement is confirmed, future work on these algorithms should be limited to further research that has already been carried out. The problem is that several of these algorithms are extremely characteristic in terms of the colour they produce. You hear them once and that's enough; you always recognise them. This is true for comb filters, for the random signal shuffling effect, for linear prediction, for the vocoder effect, for the harmonic effect...

This is the real challenge for the composer of electroacoustic music today: pure sound research seems to have reached its limits. The creator has to work with tools that are becoming more and more standardised and typified, and from them he must be able to derive a personal expression. This runs counter to the ageold image of electroacoustics as an inexhaustible source of new sound materials. Is it serious if one recognises the device or the treatment? I don't think so. It is ridiculous that a composer of instrumental music should be concerned about the timbral recognition of the instruments he uses in his works. Why should it be different for electroacoustics? On the contrary, if the composer could be less preoccupied with the novelty of the materials, and more focused on the correctness of form and the functionality of the musical gestures he sets up, I think that electroacoustic music would have finally reached a necessary maturity after so many years of pretended youth.

In electroacoustics, the exposition of sound materials has supplanted the composition with sound materials for too long. The result is a surprisingly weak form. From the point of view of form, the pieces have never gone beyond the state of introduction or collage, for lack of a coherent theory of timbre within everyone's reach.

\footnotetext{
${ }^{23}$ « Nous avons probablement développé les algorithmes essentiels du traitement sonore (de nombreux spécialistes pensent qu'il est difficile d’inventer de nouveaux algorithmes qui

pourraient proposer des traitements du son totalement nouveaux). » Daniel TERUGGI, « Quel esprit pour demain ? » art. cit., p. 81.
} 


\section{Adorno and Avant-Garde Music}

And this raises the question of the historical relativity of the material, which in my opinion has become the central problem of music today. In fact, in electroacoustics as everywhere else in instrumental music, the tools carry a past with them, which leaves its mark on aesthetics. There is no need to try to regain an innocent ear; the phenomenological wonder of the pioneering era is over. Using one of the sound processing algorithms means having to come to terms with the historical circumstances that made it possible. Based on this observation, novelty, surprise and all the other components of the aesthetics of modernity must, in my opinion, be revised downwards; they no longer function as the real fuel of artistic creation.

At the present time, the dizzying development of technology makes it very difficult to incorporate it into a language of composition. The current state of the art is an unrecognisable, indefinable moment. We must learn to work with programs and devices whose speed of development is brutally overwhelming. Our survival as composers of electroacoustic music depends on being able to establish benchmarks so that we can no longer suffer but master the incessant and exponential advance of technology.

A rereading of Adorno can serve to grasp that the aesthetic value of the works does not depend on the platitude of what we show, but on the potentiality of a future capable of making sense. Aging only what has been said, not what is being said now. In other words, I preach a language in which novelty comes from the way the elements are arranged and not from their mere discovery. None of the gestures of the electroacoustic imagination is capable, on its own, of assuming the form of the work. Electroacoustic devices and instruments all carry a past within them, and we must learn to come to terms with their historical content.

\section{CODA}

Through the critical approach of Adorno's principles, I tried to broaden the possibilities of his dialectic. As we have seen, this dialectic originally presents the apparent incompatibility between a process of an ontological, objective nature, in which everything is called upon to become something else, and the existence of a subjectivity in which the emotional charge of the creator leads rather to the repetition of elements as a reflection of a problem than to transformation.

According to Adorno, the dialectical process leading to the finished work is irreversible. Contrary to this view, I would argue that the composer is likely to reshape his creative process at any time, changing the basic postulates if necessary, without losing the coherence of the overall process. The weakly binding statistical role of the basic indications necessary for the composition of the work constitutes a frame of reference which avoids going beyond certain limits.

In order to keep the notion of dialectic because of its inestimable operational value, without contradicting the reversibility of the compositional process, I have proposed to consider it as a regulative principle of the creative process and not as its constitutive status. This makes possible to think of this dialectic as if it belonged to the structure of the work, while preserving however all its reflective value with regard to the subject who makes it.

The regulation thus obtained generates a heuristic of composition, which can be applied to instrumental creation as much as to electroacoustics. But to achieve this, I had to contradict Adorno, redefine the musical work as the crystallisation of a creative process, independently of the fixity of the writing. My hypothesis is that the notions of material, neutral and shaped, can be applicable to all musics, not only that written in traditional notation. In this way, I believe I have interpreted Adorno's notion of musique informelle to its final consequences. This particular approach to Adorno wanted to highlight his creative spirit above all his other qualities. In my opinion, it is impossible to conceive of his immanent analyses without understanding that the categories that are forged at the very level of the phenomenon are there to accompany it, to surround the genesis of the musical in the most appropriate way, without reducing it to speculative categories outside the problematic of the work. This way of thinking is that of an artist, who tries to understand his own creation and that of others; thus the best analysis is the one that adapts itself in the most flexible way to the work, and which, in a way, builds itself from it. According to Jean-Louis Leleu, in his Presentation of Quasi una Fantasia,

Adorno

" [...]in a letter of 11 October 1963, confided to Krenek his plan to devote himself again to composition, once his theoretical work was completed, and to try to realise what the developments of "Vers une musique informelle" are only the abstract outlines." 24

\footnotetext{
24 «[... confiait à Krenek, dans une lettre du 11 octobre 1963, son projet de se consacrer de nouveau à la composition, une fois achevés ses travaux théoriques, et de tenter de réaliser ce dont les développements de "Vers une musique informelle" ne sont que l'épure abstraite. » Theodor W. ADORNO, « Vers une musique informelle ", art. cit., Présentation par Jean-Louis Leleu, p. XIV.
} 


\section{Adorno and Avant-Garde Music}

Adorno therefore knew better than anyone else that practice is the prerequisite for any aesthetic theory and is its nourishing source. My reading of Adorno, nourished by the importance he gave to compositional practice, was for me a starting point that led me to think that behind concepts such as "truth content", dialectic, material and informal music, there are truly operational and relevant heuristic functions to frame the creative process and thus give it a precise meaning. From there to trying to implement heuristic schemes of intelligibility based on acoustic improvisation and electro-acoustic music, the path seemed to me to have been mapped out. These models can shed additional light on the analysis of the works. They have served me partly to realise, and partly to explain the creative process of some of my works, with the hope that similar models could be applicable to the creative process of other composers. Is this the beginning of an aesthetic utopia? As Adorno says, a utopia is "to do things we don't know what they are". ${ }^{25}$ This is perhaps the best thing Adorno left to future generations: he was able to develop a rigorous approach to music, but always leaving room for utopian dreams.

\section{BIBLIOGRAPHIE AND WEBOGRAPHIE}

1) ADORNO, Theodor W. - Théorie esthétique, translated by Marc Jimenez, Paris, Klincksieck, 1995.

2) ADORNO, Theodor W. - Quasi una fantasia (Almost a fantasy), translated by Jean-Louis Leleu assisted by Ole HansenLøve and Philippe Joubert, Paris, Gallimard, 1982.

3) ARISTOTLE, The Nicomachean Ethics, translated by F. H. Peters,

4) M.A. $5^{\text {th }}$ Edition (London, Kegan Paul, Trench, Truebner \& Co., 1893), Book VI, 4, p. 134, the online library of Liberty, Liberty Fund, Inc., online in

https://oll-resources.s3.us-east 2.amazonaws.com/oll3/store/titles/903/Aristotle_0328 EBk v60.pdf.

5) BOISSIÈRE, Anne - Adorno, la vérité de la musique moderne, (The Truth in modern music) Villeneuve d'Ascq, Presses universitaires du Septentrion, 1999.

6) COURT, Raymond - Adorno et la nouvelle musique (Adorno and the new music), Paris, Klincksieck, 1981.

7) DALHAUS, Carl - "La crise de l'expérimentation » ("The crisis of experimentation"), in Contrechamps n 3, Éditions l'Âge d'Homme, 1984.

8) MCADAMS, Stephen, Emmanuel BIGAND - « Introduction à la cognition auditive » ("Introduction to auditive cognition"), Ircam (1993/McAdams 93b).

9) MANOURY, Philippe - « Le transitoire et l'éternel ou le crépuscule des modernes ?( "The transitory and the eternal or the twilight of the moderns?") » in inHarmonique ${ }^{0} 7$, janvier 1991 :

10) Musique et authenticité.

11) RATTE, Michel - « Le problème du devenir dans le concept adornien de musique informelle » ("The problem of becoming in Adorno's concept of musique informelle"), article online in : www.uqtr.uquebec.ca/AE/vol 3/ratte.htm

12) SCHAEFFER, Pierre - "La musique mécanisée » ("Mechanised music"), in Polyphonie, Paris, Richard Masse Editor, 1950.

13) SZENDY, Peter - « Musique, temps réel », Ircam (1988/Szendy 98b).

14) SZENDY, Peter - " De la harpe éolienne à la toile » ("From wind harp to the net"), Ircam (1996/Szendy 96d).

15) Daniel TERUGGI, "Quel esprit pour demain ? "("What spirit for tomorrow ?”) in La Musique électroacoustique : un bilan (Electroacoustic music, a balance), articles compiled by Vincent Tiffon, Colloquium organized by Ricardo Mandolini and Vincent Tiffon, 2000, CEAC, Lille 3 University, p. 80.

16) VINET, Hugues - " Les enjeux de la recherche et du développement technologique pour la création musicale " ("The challenges of research and technological development for musical creation"), Ircam (1998/Vinet 98a).

17) ZANARDO, Marcelo - "La dialéctica y el análisis musical ", ("Dialectic and musical analysis") article online in www.monografias.com/trabajos15/analisis-musical/analisismusical.shtml

\footnotetext{
25 « [...]faire des choses dont nous ne savons pas ce qu'elles sont ».

Theodor W. ADORNO, "Vers une musique informelle », art. cit., p. 340.
} 